\title{
Monocrotophos induced histopathological and biochemical Changes in gills, stomach and intestine of Anabas testudineus (Cuvier)
}

\begin{abstract}
Sapana Yadav
PGT Biology, Mildredian Sacred Senior Secondary School, Tundla, Firozabad (UP), India

Shreoshi Haldar

Department of Life Science Education, Regional Institute of Education, Bhubaneswar751022 (Odisha), India

\section{Deepshikha}

Department of Life Science Education, Regional Institute of Education, Bhubaneswar 751022 (Odisha), India

Animesh Kumar Mohapatra*

Department of Life Science Education, Regional Institute of Education, Bhubaneswar751022 (Odisha), India

${ }^{*}$ Corresponding author. E-mail: akmncert@gmail.com

Abstract

Monocrotophos, an organophosphate pesticide is used frequently in paddy fields of India. Although its impact of toxicity has been reported in many organisms, its effect on digestive and respiratory organs in Anabas testudineus is scanty. The Present investigation was conducted to evaluate the impact of histopathological and biochemical indices on freshwater fish A.testudineus exposed to sub-lethal concentration (45 ppm) of an organophosphorous pesticide monocrotophos (MT). Severe histoarchitectural and biochemical changes were observed in fishes exposed to monocrotophos when compared to fishes of control group. Exposure of fishes to the pesticide resulted in induction of histological abnormalities in gills, stomach and intestine. This was accompanied with reduction in total protein content and an elevation in catalase activity in gills, stomach and intestine. These structural alterations of the gills, stomach and intestine could affect respiration, digestion and absorption of nutrients which in turn could adversely affect growth and survival of the freshwater fish $A$. testudineus. The result of this investigation serves as a biomonitoring tool for the effects of organophosphorous pesticide MT on the aquatic biota.
\end{abstract}

Keywords: Catalase, Gills, Histopathology, Intestine, Monocrotophos, Protein, Stomach

\section{Article Info}

DOI:10.31018/jans.v11i2.2110

Received: May 6, 2019

Revised: June 5, 2019

Accepted: June 10, 2019

\section{How to Cite}

Yadav, S. et al. (2019).

Monocrotophos induced histopathological and biochemical Changes in gills, stomach and intestine of Anabas testudineu (Cuvier). Journal of Applied and Natural Science, 11 (2): 534 - 544 https:// doi.org/10.31018/ jans.v11i2.2110

\section{INTRODUCTION}

Freshwater ecosystem has been polluted by continuous discharge of wastewater from agricultural practices. The wastewater contains various amounts of chemical substances, such as pesticides that results in potential health hazards to live stock, especially fishes. Fishes are among the group of non-targeted aquatic organism. They serve as bioindicator of water quality and the effect of pesticides can be studied by analysing the histoarchitecture and biochemical parameters of various organs (Rao and Pillai, 2001; Bartoskova et al., 2013; Faggio et al., 2014a, b; Gobi et al., 2018. A wide variety of pesticides and insecticides are used in agricultural fields (Sumithion, Lorsbon, Aluminium chloride, Endosulfan, Monocrotophos, Chlorpyrifos, Dichlorvos, Almix 20WP, Profenofos,
Diethylphthalate, Dimethoate, Phosalone). Among them monocrotophos, an organophosphorous pesticide is used by many for rice cultivation as it is cost effective.

Review of available literature on fish and environmental pollutants indicate that the sub-lethal doses of most of the pesticides cause behavioural changes, varying extent of histopathological injuries to different organs in fishes and biochemical changes; the amount of damages are usually dependent on dose, duration of exposure and type of pesticide (Tilak et al., 2005; Cengiz and Unlu, 2006; Mishra et al., 2006, 2008; Ghanbahadur and Ghanbahadur, 2012; Oguei et al., 2013; Senapati et al., 2013; Pandey et al., 2014; Ullah et al., 2014; Ullah and Zorriehzahra, 2015). Recently, Marigoudar et al. (2018), and Zahran et al. (2018) reported that chlorpyrifos induced patho- 
logical lesions in gills, liver, eye and brain of Oreochromis niloticus, Mugil cephalus and Chanos chanos. It has been observed by many researchers that monocrotophos which reaches to the water bodies such as ponds and rivers affect fishes (Remia et al., 2008; Velmurugan, 2007; Muthukumaravel, 2013). When it comes in contact with the internal organs, affects the histoarchitecture of the tissues and shows irreversible changes in the metabolic activities and ultimately affects the human beings consuming them as fishes are an indigenous, delicious and high quality meat species. Histological changes provide a rapid method to detect effects of irritants, especially chronic ones, in various tissues (Oruc, 2012).

Prolonged exposure of pesticides leads fishes to live in a stress condition which causes biochemical changes due to destruction of histology of the tissues. Secondary metabolites of pesticides induce severe biochemical and enzymatic changes in aquatic organisms (Rawat et al., 2002; Tiwari and Singh, 2009). Fishes exposed to different pesticides consume less oxygen as secondary metabolites reacts with oxygen present in water. Pesticide pollution alters several enzymatic pathways in organisms. Muley et al. (2007) in Labeo rohita and Prasanth et al. (2008) in Cirrhinus mrigala reported decrease in total protein and increase in free amino acids level in gill and liver in response to cypermethrin exposure and suggested high protein hydrolytic activity due to elevation of protease activity. Pesticides also affect the activity of enzymes and alter their level so they can be used as biomarkers. Reactive oxygen species (ROS) formed during biotransformation of xenobiotics damage cell structures via oxidation. To reduce the ROS effects, cell produce enzymes such as catalase involved in the antioxidant process (Van der Oost et al., 2003). Catalase is found nearly in all the organisms that catalyse the decomposition of $\mathrm{H}_{2} \mathrm{O}_{2}$. Antioxidant parameters are used as health indicators to detect the structural and functional status of fish under stress conditions (Moraes et al., 2007; Van der Oost et al., 2003).

The objective of the present study was to analyze and comprehend the acute toxic effect of the organophosphorous pesticide monocrotophos (MT) on histological alterations in gill, stomach and intestine and biochemical parameters in freshwater fish Anabas testudineus.

\section{MATERIALS AND METHODS}

A. testudineus a fresh water fish was selected for the study as it has economic value and easily available throughout the year. The fishes were collected from Central Institute of Fishery and Aquaculture (CIFA), Bhubaneswar, Odisha. The average length of fishes used for the study was 11 to $13 \mathrm{~cm}$ and weight 40 to $60 \mathrm{~g}$. The fishes were disinfected with $1 \%$ potassium permanganate solution. They were acclimatized to laboratory condition in large tanks $(60 \times 60 \times 90 \mathrm{~cm})$ for 20 days containing well aerated dechlorinated ground water. During acclimatization fishes were fed with fish pellets developed by CIFA. The physico-chemical characteristics of water at regular intervals were carried out in the laboratory throughout the study Table 1).

After acclimatization, fishes were divided into two groups. One group of 15 fishes i.e. control group was maintained in normal water in a tank containing 125 litres and the other group of 30 fishes i.e. experimental group was maintained in a separate tank containing 250 litres of water having $45 \mathrm{ppm}$ monocrotophos concentration (sublethal). The normal water and pesticide mixed water was renewed on every $2^{\text {nd }}$ day in control group and experimental group tanks respectively during the period of study. Each day, the dead fishes if any were counted, recorded and removed from the tank immediately to avoid depletion of dissolved oxygen (DO) level which may adversely affect other fishes.

To study the effect of monocrotophos, the fishes of both control and experimental group were sacrificed on $10^{\text {th }}$ and $20^{\text {th }}$ day of the experiment. They were dissected under normal saline and gills, stomach and intestine were fixed in aqueous Bouin's fluid. Following fixation the tissues were dehydrated through graded series of ethanol, infiltrated in melted paraffin $\left(60^{\circ} \mathrm{C}\right)$, embedded on paraffin block, and sectioned at $5 \mu \mathrm{m}$ by using rotatory microtome. The tissue sections were spread on slides, rehydrated and stained with Ehrlich haematoxylin and eosin. Stained sections on slides were then mounted with Dextran Plasticizer Xylene (DPX) and covered with a cover glass. For biochemical studies, gills, stomach and intestine were taken out after dissection in normal saline on $10^{\text {th }}$ and $20^{\text {th }}$ day of both control and experimental groups for total protein content estimation by following standard method of Bradford (1976) and catalase activity by Aebi (1983).

\section{RESULTS AND ANALYSIS}

Histoarchitectural changes: The microscopic histoarchitecture of normal gills of $A$. testudineus

Table 1. Physico-chemical characteristics of water used for the study.

\begin{tabular}{ll}
\hline Parameters & Calculated value \\
\hline Temperature & $30 \pm 2^{0}$ \\
Turbidity & 6.7 silica units \\
$\mathrm{pH}$ at $30^{\circ} \mathrm{C}$ & $7.4 \pm 0.05$ \\
Total hardness $\left(\mathrm{CaCO}_{3}\right)$ & $198 \pm 6(\mathrm{mg} / \mathrm{L})$ \\
$\mathrm{BOD}$ & $7-10 \mathrm{ppm}$ \\
$\mathrm{COD}$ & $\mathrm{Nil}$ \\
Dissolved oxygen $(\mathrm{DO})$ & $5.5 \pm 0.5 \mathrm{mg} / \mathrm{L}$ \\
\hline
\end{tabular}


showed a row of long thin filaments, the primary lamellae projecting from the gill arch like the teeth of a comb. On its distal and ventral surface, there were the secondary lamellae which consisted of an envelope of epithelial cells, usually one layer thick, supported and separated by pillar cells arranged in rows. The gills of control group fishes had normal gill arch, primary gill lamellae and secondary gill lamellae and epithelial cells (Figs. 1 and 2). Exposure of fishes to sub-lethal dose of $45 \mathrm{ppm}$ concentration of monocrotophos for 10 days induced histopathological alterations like lamellar fusion, telanglectasia (marked dilation of terminal blood vessels) of the secondary lamellae, desquamation and necrosis of epithelia in the gills (Figs. 3 and 4). Prolonged exposure of fishes to pesticide (20 days) resulted in detachment of epithelium and disintegration of lamellar tissues (Fig. 5); and hyperplasia, mucous deposition and haemorrhage (Fig. 6).

The stomach of control group fishes showed normal histology of all four layers i.e. mucosa, sub mucosa, muscularis and serosa. Mucosa layer folded into variable depths is composed of a superficial epithelium of single layer of columnar cells, lamina propria and folded stratum compactum (Fig. 7). The submucosa layer is highly vascularized with a thick layer of connective tissue extending into the lamina propria (Fig. 8). Muscularis layer is thin and innervated by blood capillaries (Fig. 7). Fishes exposed to the sublethal concentration of monocrotophos for 10 days showed atrophy of musculature, disintegrated submucosa and mucosa epithelium with degenerated mucosal columnar epithelium (Fig. 9 and 10). Prolonged exposure (20 days) to monocrotophos induced heavy atrophy of musculature, disintegration of submucosa and mucosa (Fig. 11) and cytoplasmic vacuolization with pyknotic nuclei in mucosa epithelial cells (Fig 12).
The intestine of control group fishes showed normal four histological layers i.e. mucosa, submucosa, muscularis and serosa (Fig. 13). The mucosal layer is produced into villi lined by columnar epithelial cells with centrally and basally placed nuclei (Fig. 13 and 14). Mucous cells were present all over the intestinal mucosa. Intestinal villi were covered by a thin layer of tissue matrix. Lamina propria of submucosa was formed of loose connective tissue fibres. Muscularis layer composed of inner circular muscle fibres and outer longitudinal muscle fibres while serosa layer composed of a single layer of flat cells with blood capillaries and connective tissue fibres (Fig. 13 and 14). In case of experimental group fishes exposed to pesticide for 10 days, an alteration in the histoarchitecture of intestine was observed. There was atrophy of musculature (M), disintegration of submucosa (SM) and mucosa (MU), degeneration of columnar epithelial cells, degeneration of lamina propria and atrophy of lamina propria and disintegration of mucosa epithelium (Fig. 15 and 16). Severity of tissue damages like heavy atrophy of musculature, disintegrated sub-mucosa and mucosa (Fig. 17), cytoplasmic vacuolization and pyknotic nuclei in mucosa epithelial cells (Fig. 18) was recorded in fishes of experimental group exposed to monocrotophos for 20 days.

Biochemical changes: The result of the present study clearly showed that monocrotophos had a negative impact on total tissue protein content of gills, stomach and intestine in comparison to fishes of control group (Table 1, Fig. 19). In control group fishes, the total tissue protein content of gills, stomach and intestine after 10 days was in order of intestine > gill >stomach and after 20 days in order of intestine $>$ stomach $>$ gill. The variation in distribution suggests differences in metabolic calibre of various tissues. Fishes exposed to sublethal concentration of monocrotophos showed

Table 1. Percentage change in total protein content (mg of tissue/g of extract) of gill, stomach and intestine of control and fishes exposed to $45 \mathrm{ppm}$ of monocrotophos for 10 and 20 days.

\begin{tabular}{ccccccc}
\hline Organ and & \multicolumn{5}{c}{ Days of exposure } \\
\cline { 2 - 6 } tissue & \multicolumn{7}{c}{$10^{\text {th }}$ day } & & & $20^{\text {th }}$ day & \\
\cline { 2 - 6 } & Control & Treated & \% change & Control & Treated & \% change \\
\hline Gills & 181.73 & 163.43 & 10.06 & 198.95 & 140.85 & 29.20 \\
Stomach & 177.85 & 141.20 & 20.60 & 206.80 & 120.65 & 41.65 \\
Intestine & 190.06 & 128.71 & 32.27 & 221.67 & 145.93 & 34.16 \\
\hline
\end{tabular}

Table 2. Percentage change in catalase activity $\left(\mathrm{nmol} \mathrm{H}_{2} \mathrm{O}_{2}\right.$ consumed $\mathrm{mg}$ protein $\left.{ }^{-1} \mathrm{~s}^{-1}\right)$ in gill, stomach and intestine of control and fishes exposed to $45 \mathrm{ppm}$ of monocrotophos for 10 and 20 days.

\begin{tabular}{ccccccc}
\hline Organ and \begin{tabular}{c}
\multicolumn{5}{c}{ Days of exposure } \\
tissue
\end{tabular} & \multicolumn{7}{c}{ 20 } & 20 day \\
\cline { 2 - 6 } & Control & Treated & \% change & Control & Treated & \% change \\
\cline { 2 - 6 } & 203.91 & 306.83 & 33.54 & 237.03 & 440.47 & 46.18 \\
Gills & 195.09 & 257.44 & 24.21 & 230.80 & 390.27 & 40.86 \\
Stomach & 195.09 & 13.79 & 252.12 & 405.09 & 37.75 \\
Intestine & 206.25 & 239.25 & &
\end{tabular}


Yadav, S. et al. / J. Appl. \& Nat. Sci. 11(2): 534 - 544 (2019)

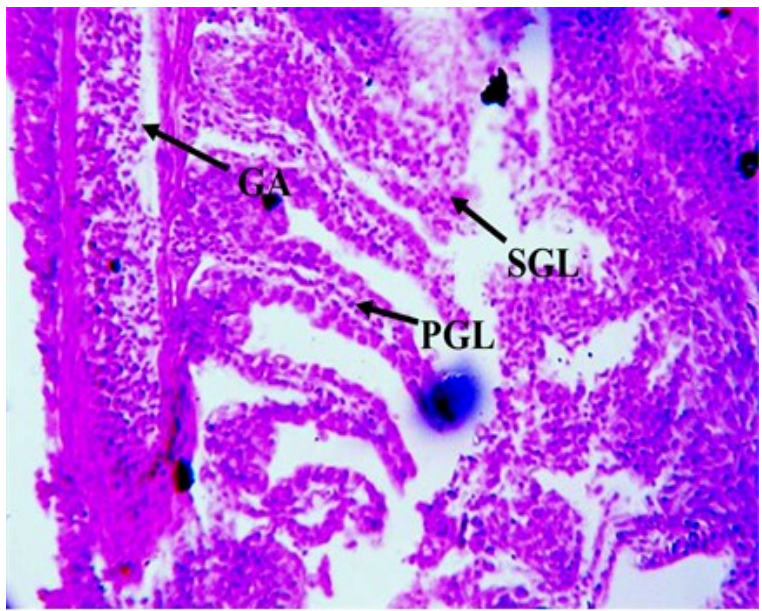

Fig. 1. Section of gills of control Anabas showing normal gill arch (GA), primary gill lamellae (PGL) and secondary gill lamellae (SGL), 400X.

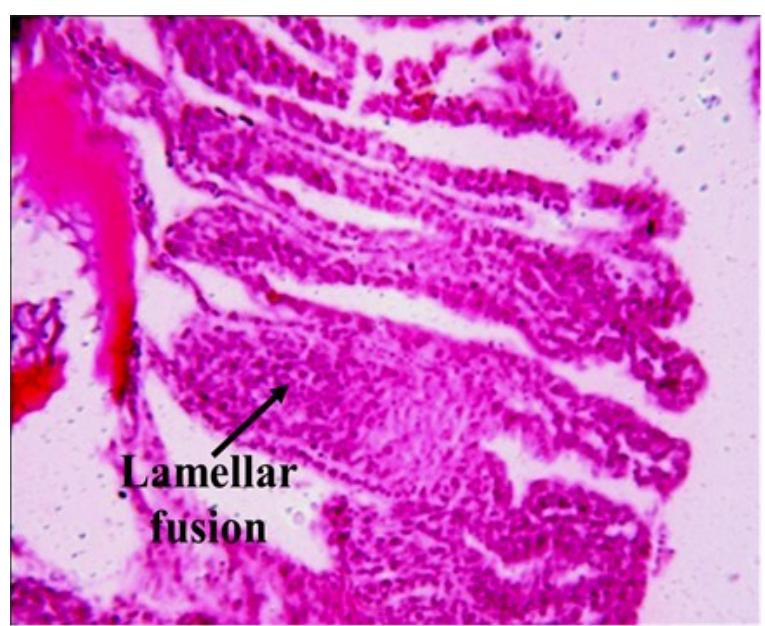

Fig. 3. Section of gills of $10^{\text {th }}$ day treated Anabas showing lamellar fusion, 400X.

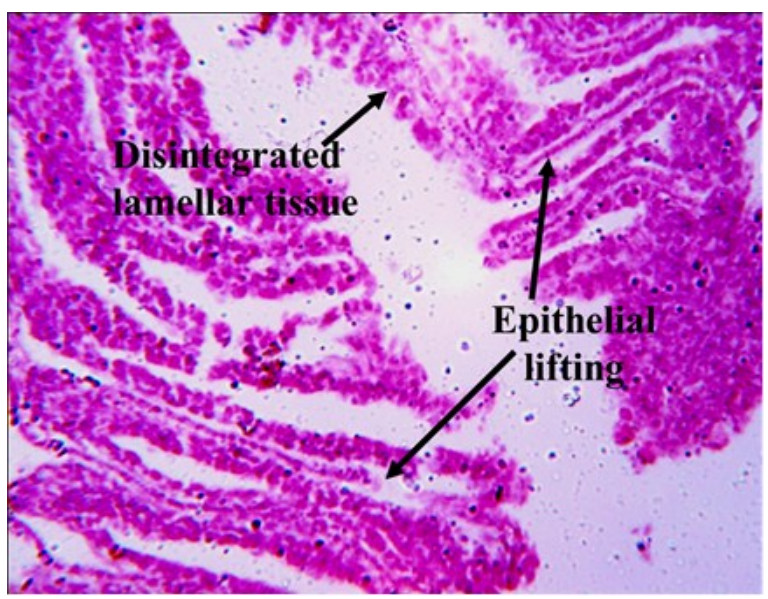

Fig. 5. Section of gills of $20^{\text {th }}$ day treated Anabas showing detachment of epithelium and disintegration of lamellar tissues, 400X.

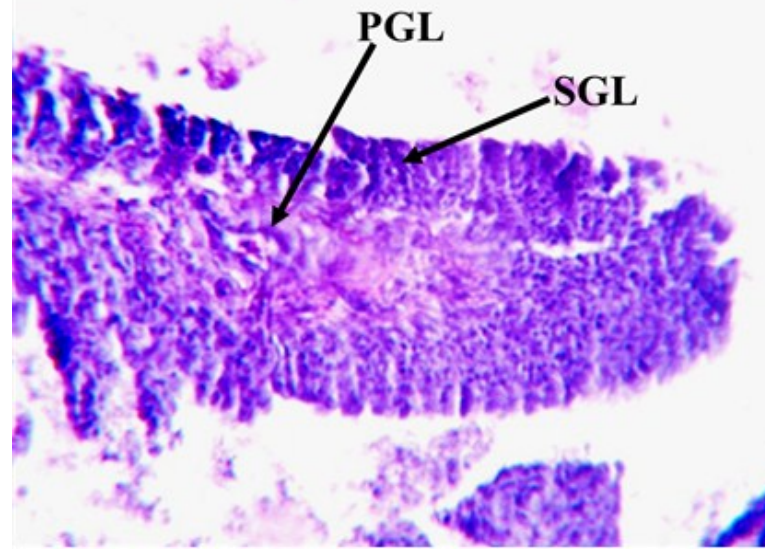

Fig. 2. Section of gills of control Anabas showing primary gill lamellae (PGL) and secondary gill lamellae (SGL), 400X.

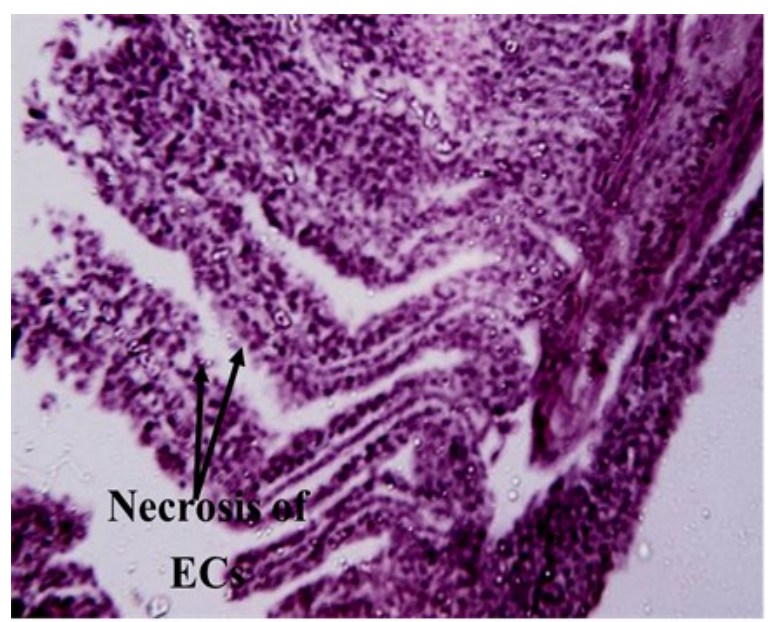

Fig. 4. Section of gills of $10^{\text {th }}$ day treated Anabas showing desquamation and necrosis of epithelial cells (ECs), 400X.

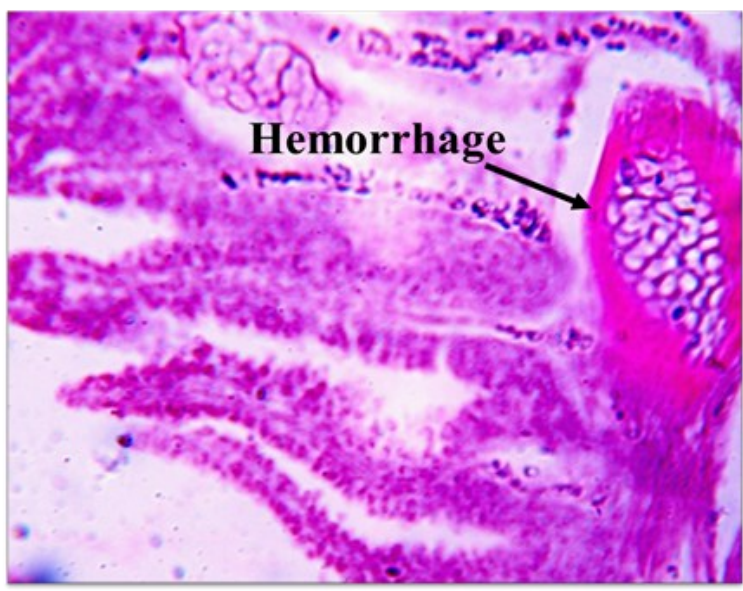

Fig. 6. Sections of gills of $20^{\text {th }}$ day treated Anabas showing hyperplasia and haemorrhage, 400X. 
Yadav, S. et al. / J. Appl. \& Nat. Sci. 11(2): 534 - 544 (2019)

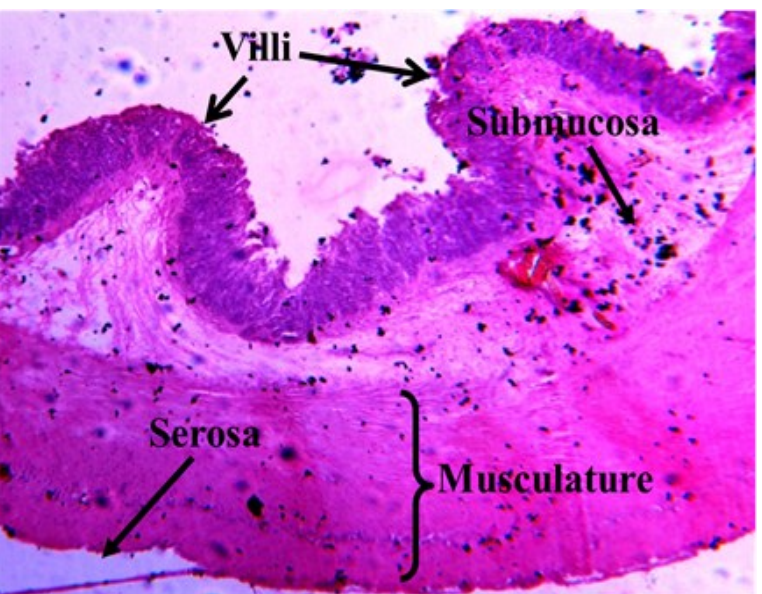

Fig. 7. Section of stomach of control Anabas showing normal histoarchitecture, 400X.

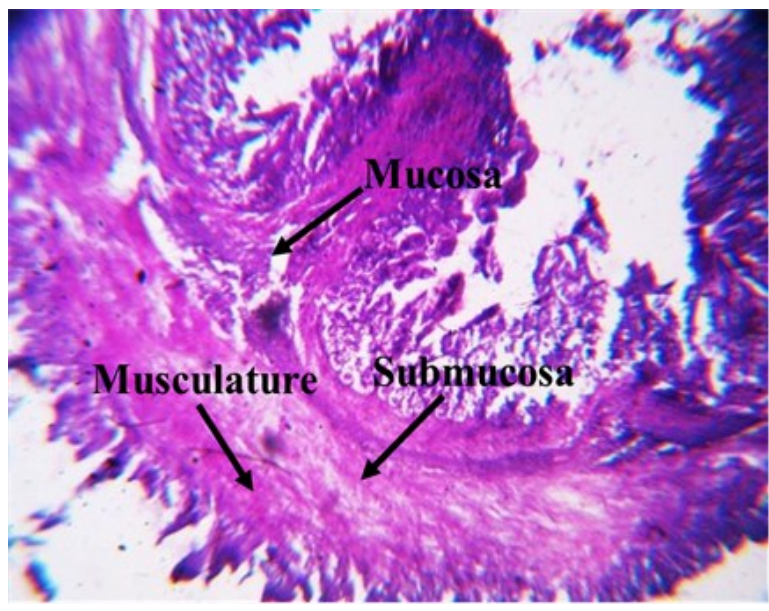

Fig. 9. Section of stomach of $10^{\text {th }}$ day treated Anabas showing atrophy of musculature and disintegrated submucosa and mucosa, 400X.

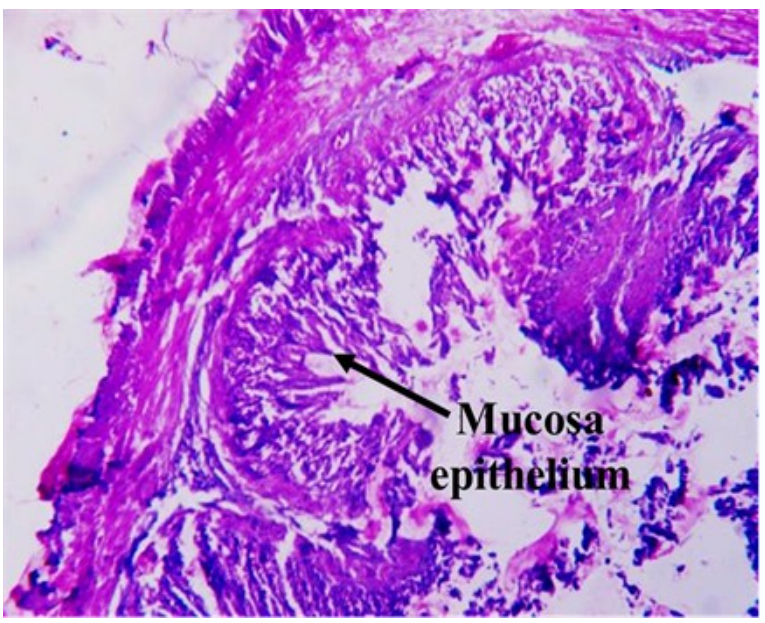

Fig.11. Section of stomach of $20^{\text {th }}$ day treated Anabas showing heavy atrophy of musculature and disintegrated submucosa and mucosa, 400X.

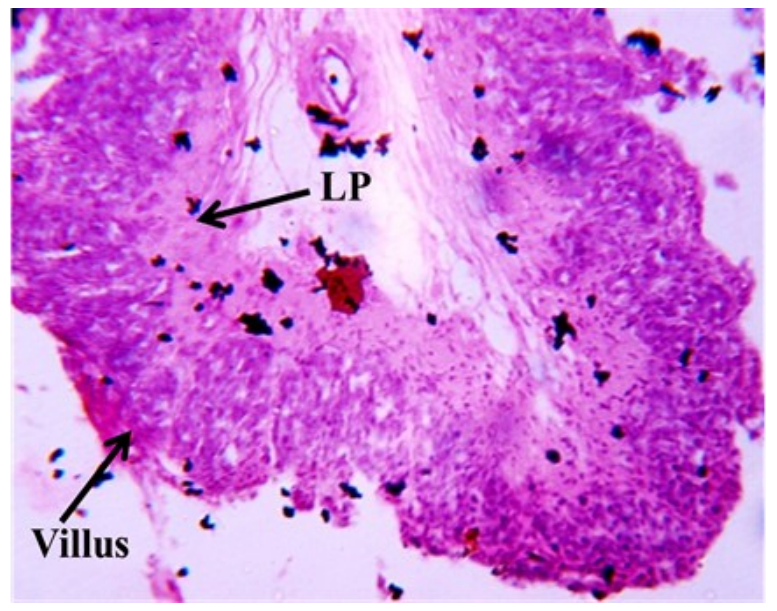

Fig. 8. Section of stomach of control Anabas showing normal villus and lamina propria (LP), 400X.

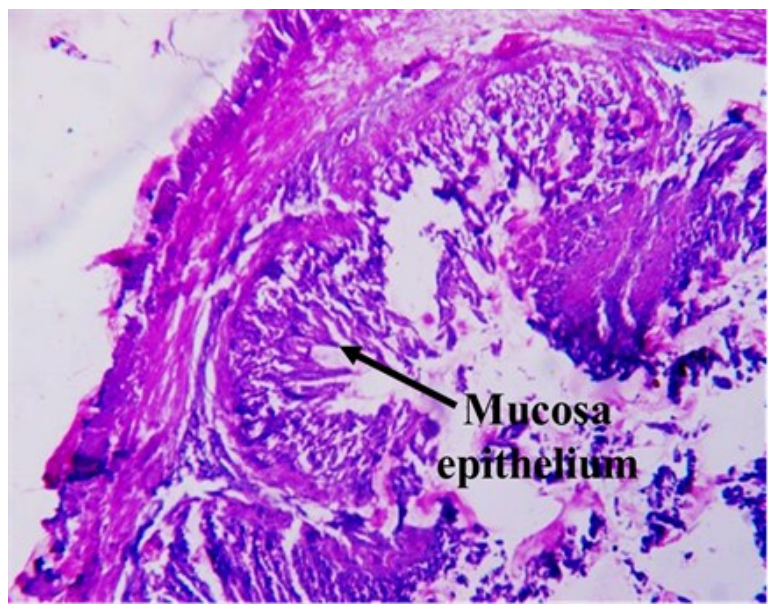

Fig. 10. Section of stomach of $10^{\text {th }}$ day treated Anabas showing atrophy of musculature, disintegrated submucosa and mucosa epithelium, 400X.

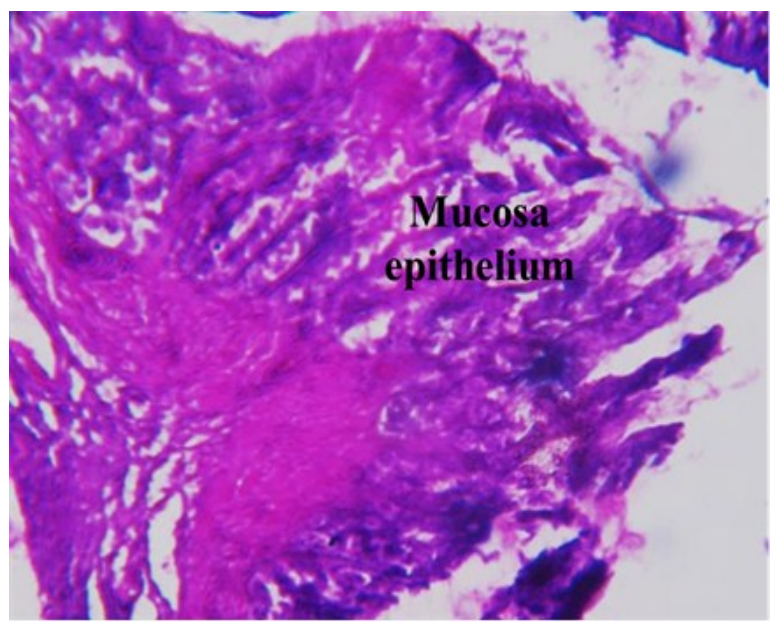

Fig. 12. Section of stomach of $20^{\text {th }}$ day treated Anabas showing cytoplasmic vacuolization and pyknotic nuclei mucosa epithelial cells, 400X. 
Yadav, S. et al. / J. Appl. \& Nat. Sci. 11(2): 534 - 544 (2019)

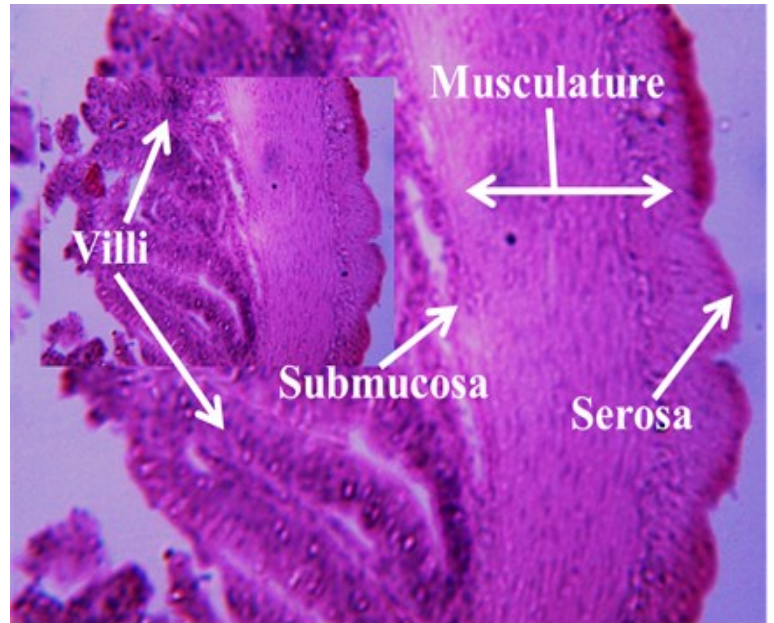

Fig. 13. Section of intestine control Anabas showing normal histoarchitecture, 400X.

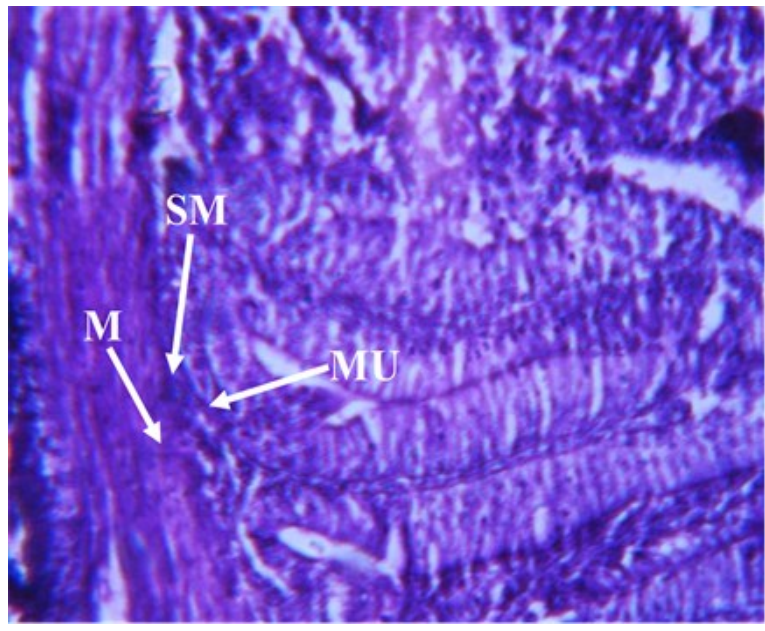

Fig. 15. Section of intestine of $10^{\text {th }}$ day treated Anabas showing atrophy of musculature (M) and disintegrated submucosa (SM) and mucosa (MU), 400X.

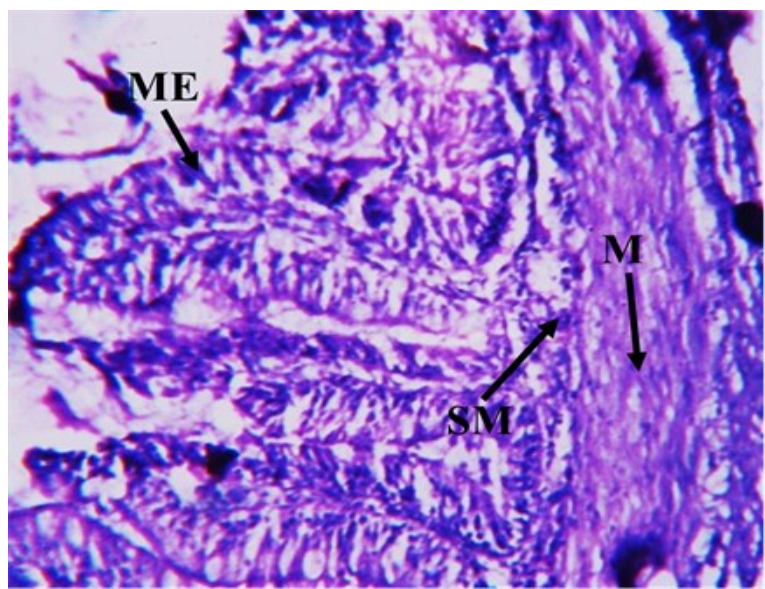

Fig. 17. Section of intestine of $20^{\text {th }}$ day treated Anabas showing heavy atrophy of musculature and disintegrated submucosa and mucosa, 400X.

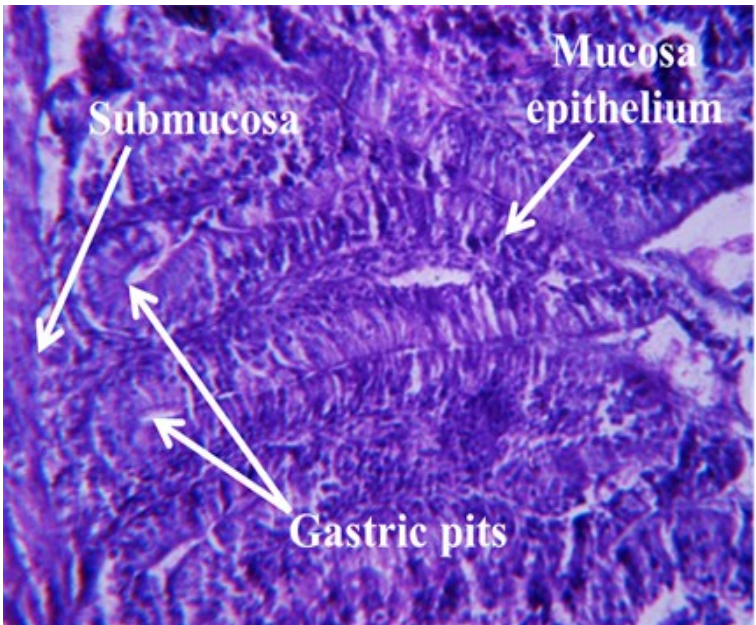

Fig. 14. Section of intestine of control Anabas showing normal villus (V) and lamina propria (LP), 400X.

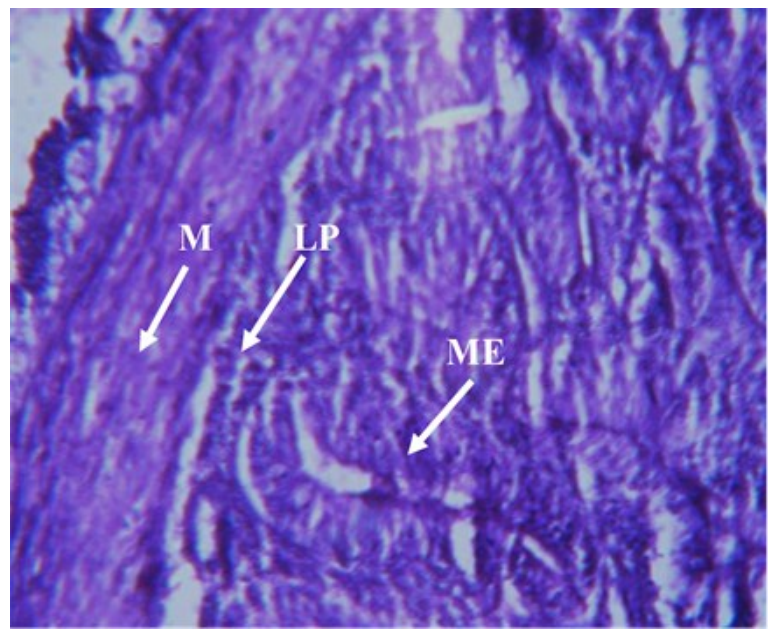

Fig. 16. Section of intestine of $10^{\text {th }}$ day treated Anabas showing atrophy of lamina propria, disintegrated mucosa epithelium (ME), 400X.

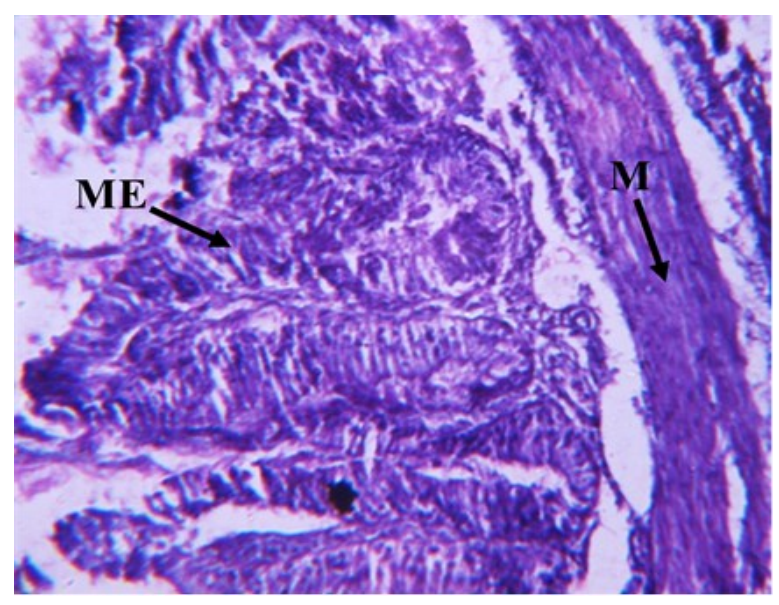

Fig. 18. Section of intestine of $20^{\text {th }}$ day treated Anabas showing cytoplasmic vacuolization and pyknotic nuclei mucosa epithelial cells, 400X 
Yadav, S. et al. / J. Appl. \& Nat. Sci. 11(2): 534 - 544 (2019)

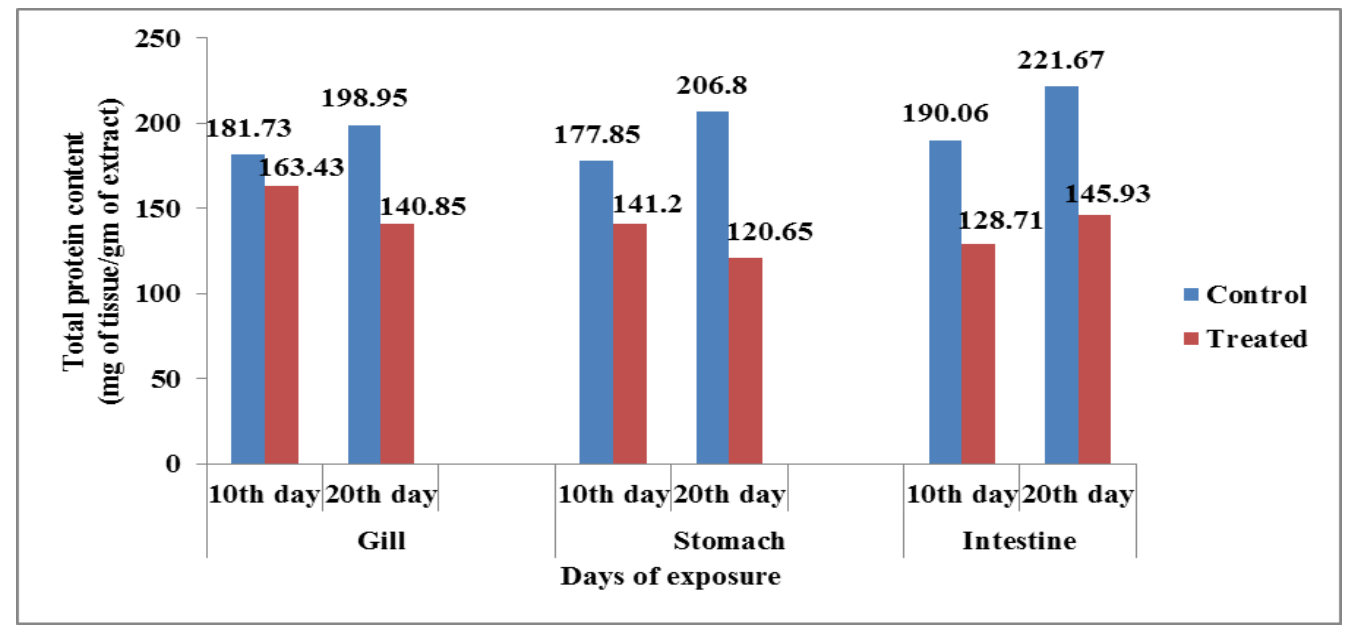

Fig. 19. Total protein content of gill, stomach and intestine of control and experimental fishes (exposed to $45 \mathrm{ppm}$ of monocrotophos) for10 and 20 days.

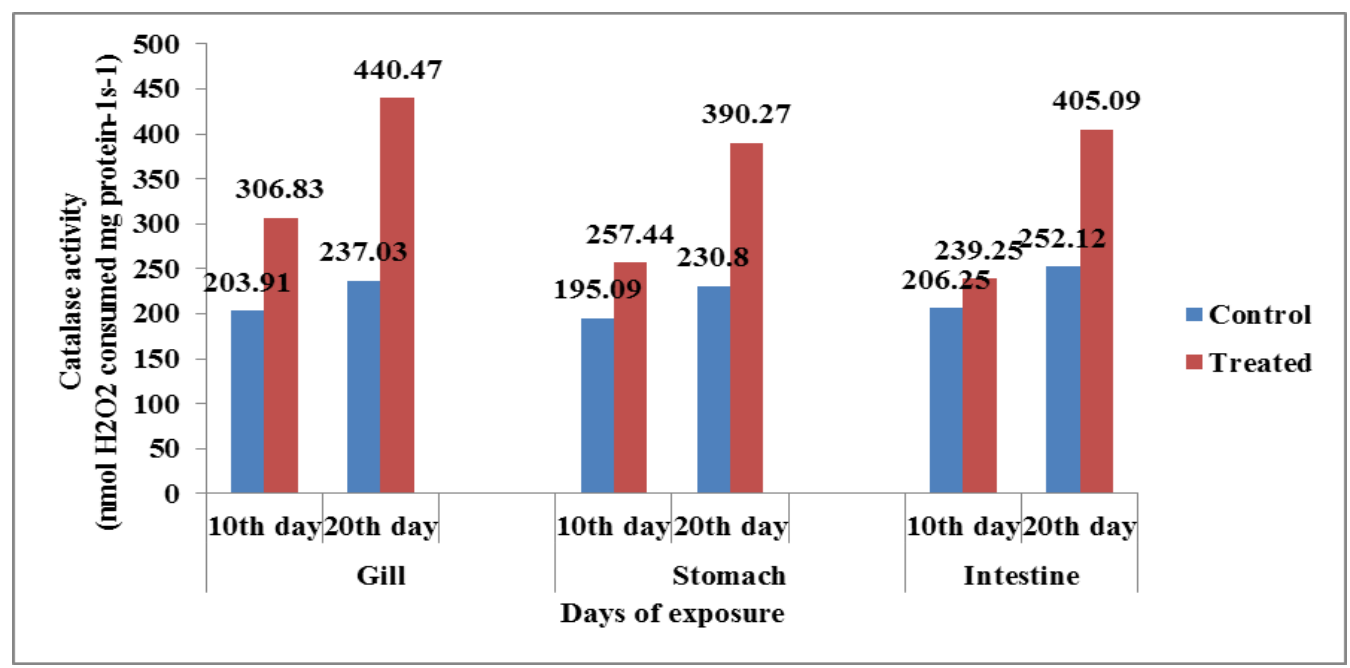

Fig. 20. Comparison between the catalase activity of gills, stomach and intestine in control and fishes exposed to $45 \mathrm{ppm}$ of monocrotophos solution for 10 and 20 days.

significant depletion of total tissue protein content in gills, stomach and intestine. After 10 days of exposure it was in order of Intestine < Stomach < Gill and after 20 days it was Stomach < gill < intestine. The severity of monocrotophos on total protein content after 10 days of exposure was maximum in intestine $(32.27 \%)$ and minimum ingills $(10.06 \%)$. In case of prolonged exposure of fishes to monocrotophos for 20 days, the maximum decrease in total protein content was observed in stomach $(41.65 \%)$ and minimum in Gills $(29.20 \%)$ when compared with their respective controls.

A significant increase in catalase activity was observed in fishes exposed to sub-lethal concentration of monocrotophos (Table 2, Fig. 20). This increase can be explained by the stimulation of antioxidant defence system in all tissues under study. In control group fishes, the catalase activity after $10^{\text {th }}$ and $20^{\text {th }}$ day was in order of intestine $>$ gill > stomach. Fishes exposed to monocrotophos pesticide showed enhanced activity of catalase in tissues after 10 days was in order of gill < stomach < intestine and after 20 days it was in order of gill < stomach < intestine. Maximum percentage of enhancement of catalase activity after 10 days of exposure to pesticide was observed in gills $(33.54 \%)$ and minimum in intestine (13.79\%). When fishes were exposed for a prolonged period (20 days), a further enhancement in catalase activity was recorded maximum in gills $(46.18 \%)$ and minimum in intestine (37.75\%).

\section{DISCUSSION}

Histopathological changes have been widely used as biomarkers for monitoring the effects of pollutants on specific target organs like gills, liver, kidney and gut of fishes that are responsible for vital functions (Schwaiger, et al., 1997; Teh et al., 1997; Gernhofer et al., 2001 and Joseph and Raj, 
2011). The alterations found in these organs on exposure to chemicals like pesticides are normally easier to identify than the functional ones and serve as markers of damage to animal health (Ceingiz and Unlu, 2003).

Gills in fishes are not only involved in respiration but also play an important role in osmoregulation and elimination of nitrogenous wastes as gills are directly exposed to external environment. Various dissolved toxicants from water constantly enter through the surface of gill and get accumulated in the tissues. Several histological alterations were recorded in the present study of gills of $A$. testudiens after 10 days of exposure to sublethal concentration of monocrotophos (45ppm) such as hypertrophy of secondary gill lamellae, telanglectasia, fusion of secondary lamellae and vacuolization. The damage was more severe and progressive after 20 days of exposure to pesticide. The gill epithelium surrounding the axis of primary and secondary lamellae were damaged to great extent. There was desquamation and necrosis of epithelial lining, disintegration of lamellar tissues and haemorrhage. The results of the present study are consistent with the histopathological work carried out by Katuli et al. (2014) in Rutilus rutilus, Rosety-Rodriguez et al. (2002) in Scophthalmus maximus, Maharajan and Parurukmani (2012) in Catla catla and Ghasemzadeh et al. (2015) in Scatophagus argus. They all reported severe necrotic lamellae in gill tissues, edema, epithelial lifting, lamellar fusion and shortening up of secondary lamellae on exposure to different pesticides. Similarly, Zahran et al., (2018) in Oreochromis niloticus and Devi and Mishra (2013) in Channa punctatus observed histopathological changes in gills on exposure to Chlorpyrifos. They noticed damages such as fused tips of secondary lamellae, decreased inter-lamellar space, mucous accumulation and hyperplasia of epithelium. The results of the present study confirms the above findings i.e mucous accumulation inside secondary lamellae and decreased inter-lamellar cell mass which has also been reported by Karmakar et al. (2015) in Labeo rohita on exposure to malathion. Earlier workers like De Silva and Samayawardhena (2002) and Al-Ghanin et al. (2008) have reported that reduced gaseous exchange in fishes exposed to toxicants was due to increased mucous deposition on gills and damaged gill lamellae. In the present study, death of fishes that occurred during experimental period might be due to degeneration of respiratory epithelium and the damage of gill tissues leading to tissue hypoxia and consequent decrease in enzyme metabolism. Histopathological alterations in the alimentary canal of $A$. testudineus in the present study showed the toxicity of monocrotophos. Exposure to monocrotophos showed pathological lesion in stomach with atrophy of musculature, disintegrated submu- cosa and mucosa epithelium, degeneration of columnar epithelial cells of mucosa. Prolonged exposure showed heavy atrophy of musculature and disintegrated submucosa and mucosa and cytoplasmic vacuolization and pyknotic nuclei in mucosa epithelial cells. Senapati et al. (2013) in Anabas testudineus upon exposure to Almix 20WP herbicide reported degeneration and vacuolation of the gastric epithelium, columnar epithelial cells and damaged gastric glands. Ghanbahadur and Ghanbahadur (2012) observed sub-mucosal vacuolization and shrinkage of mucosal folds in Rasbora daniconius on exposure to endosulfan. The gastric glands present in submucosa secrete gastric juice contains enzymes for digestion of proteins. The mucosal cells secrete mucous that protect gastric epithelium from gastric acidity and other chemical reaction. The distortion of columnar epithelium as observed in the present study might be due to impaired secretion of mucous that protects it from gastric acidity and chemical reactions.

In the present study, histopathological lesions were detected in intestine of $A$. testudineus due to monocrotophos toxicity. The concomitant changes in the intestine of fishes exposed to pesticide in the present study were atrophy of musculature, disintegration of submucosa and mucosa, degeneration of lamina propria and distortion of columnar epithelial cells. Senapati et al. (2013) reported similar type of histopathological changes in the intestine of Anabas testudineus like degeneration of columnar epithelial cells, lamina propria and prominent luminal mucous secretion on exposure to herbicide Almi 20WP. Ghanbahadur and Ghanbahadur (2012) in Rasbora daniconius and Sharma et al. (2001) in Cirrhina mrigala also showed similar histological alterations in the intestine due to toxicological effects of different pesticides. The results of the present study showed severity of tissue damages like heavy atrophy of musculature, distortion of villi, cytoplasmic vacuolization and pyknotic nuclei in mucosal epithelial cells due to prolonged exposure of fishes to monocrotophos. These observations are consistent with the result of Ravanaiah and Narasimha (2010) carried out in Tilapia mossambica.

Proteins are important organic substances required by organism as an alternative source of energy and tissue building (Yeragi et al., 2003). The level of total tissue protein used as a biochemical parameter to evaluate the toxicity of pollutants. The result of the present study showed significant decrease in total tissue protein content in gills, stomach and intestine in fishes exposed to monocrotophos pesticide after 10 days in comparison to fishes of control group. Several workers have also observed decline in tissue protein under toxic stress of various chemicals (Susan et al. (1999); Jha and Verma (2002); Tilak and Yacob 
(2002); Hazarika et al. (2003), Tilak et al. (2003); Vishal (2004); Kalender et al. (2005); Venkataramana et al. (2006); Rohankar et al. (2012) and Nagarajun and Rathnaman (2013). Remia et al. (2008) suggested that reduction of total tissue protein may be due to proteolysis and increased metabolism under toxicant stress. A progressive hyperproteinemia was observed when fishes were exposed to monocrotophos for a prolonged period (20 days). Similar trend of severity of pesticides on tissue protein when exposed for a prolonged period was reported by Al-Kahtani (2011); Tripathi and Yadav (2015); Sulfath et al. (2013); Muley et al. (2007); Jenkins et al. (2003). The decline in tissue protein in gills, stomach and intestine might be due to enhanced breakdown of proteins into amino acids for various metabolic activities. There are two possible reasons to degrade tissue protein under stress condition due to toxicity of pesticides i.e. synthesis of membrane lipoproteins for repairing cell damages and increased energy requirement. The decline in total tissue protein might be due to reduced or inhibition of protein synthesis due to tissue necrosis (Jyothirmayee et al., 2006).

Catalase is an important enzyme that plays an important role in removing $\mathrm{H}_{2} \mathrm{O}_{2}$ by decomposing it in to $\mathrm{H}_{2} \mathrm{O}$ and molecular $\mathrm{O}_{2}$. Sulfath et al. (2013) showed decreased catalase activity in Oreochromis mossambicus on exposure to lindane. They suggested that it might be due to reduction in NADPH concentration in relation to high energy requirement or immense production of free radicals on exposure to lindane. Pesticide induced inhibition of catalase activity has also been reported in Chana punctatus by Sharma et al. (2001) on exposure to endosulfan, Sayeed et al. (2003) on exposure to delta methrin and Tripathi and Singh (2013) on exposure to alphamethrin and in Danio rerio by Ansari and Ansari (2014) on exposure to Alphamethrin. However, the results of the present study showed significant augmented catalase activity in gills, stomach and intestine of monocrotophos exposed fishes in comparison to tissues of control group fishes. Similar results have been reported by Moraes et al. (2007) in Leporinus obtusidens and Karamati et al. (2010) in Rutilus rutilus. The increase in catalase activity as observed in the present study indicated the excess production of $\mathrm{H}_{2} \mathrm{O}_{2}$ due to metabolism of monocrotophos as a defence of the organism against oxidative damage as catalase acts on $\mathrm{H}_{2} \mathrm{O}_{2}$.

\section{Conclusion}

Pesticides are often considered a quick, easy, and inexpensive solution for controlling weeds and insect pests in agriculture. It has contaminated almost every part of our environment and residues are found in soil and air and in surface and ground water across the country. Present study showed toxicity of monocrotophos in Anabas testudineus. It induced histological abnormalities in gills; stomach and intestine together with reduction in total tissue protein content and an elevation in catalase activity. Adverse effects of pesticide could affect growth and survival of the fish due to structural alterations of the gills, stomach. If pesticides are selected wisely, used in combination with other pest control measure, and applied safely, the pollution of our surface waters and contamination of aquatic life can be avoided. Besides for safe use of pesticides more experimental work should be performed to determine the concentration and time of exposure that don't induce significant sublethal effects on fish.

\section{REFERENCES}

1. Aebi, H. E. (1983). Catalase. In: Bergmeyer, H.U., Ed., Methods of Enzymatic Analysis, Verlag. Chemie., Weinhem, 273- 286.

2. Al-Ghanin, K. A., Al-Kahem Al-Balawi, H. F., Al-Akel, A. S., Al-Misned, F. A. Z. And Annazri, A. (2008) Ethological response, haematological and biochemical profiles of carp, Cyprinus carpio exposed to trichlorfon. J. Food Agri. Environ. 6 (3 \& 4), 473 - 479.

3. Al-Kahtani, M. A. (2011). Effect of an insecticide Abamectin of some biochemical characteristics of Talapia fish, Orechromis niloticus. Amer. J. Agri. Biol. Sci. 6 (1): 62 - 68.

4. Ansari, S. and Ansari, B. A. (2014). Toxic effect of alphamethrin on catalase, reduced glutathione and lipid peroxidation in the gill and liver of zebra fish, Danio rerio. World J. Zool. 9 (3): 155 - 161.

5. Bartoskova, M., Dobsikova, R., Stancova, V., Zivna, D., Blahova, J., Marsalek, P., Zelníckova, L., Bartos, M., Di Tocco, F. C., Faggio, C. (2013). Evaluation of ibuprofen toxicity for zebrafish (Danio rerio) targeting on selected biomarkers of oxidative stress. Neuro. Endocrinol. Lett. 34:102-108

6. Bradford, M. M. (1976). A rapid and sensitive method for the quantitation of microgram quantities of protein utilizing the principle of protein-dye binding. Analytical Biochemistry, 72 (1-2): 248-254.

7. Cengiz, E. and Unlu, E. (2003). Histopathology of gills in mosquito fish, Gambusia affinis after long term exposure to sub-lethal concentrations of malathion., J. Environ. Sci. Healt. B., 38(5): 581-589.

8. Cengiz, E. I. and Unlu, E. (2006). Sub-lethal effects of commercial Deltamethrin on the structure of the gill, liver and gut tissues of mosquito fish Gambusia affinis: a microscopic study. Environ. Toxicol. Pharmacol., 21: 246-253.

9. De Silva, P. M., and Samayawardhena, L. A. (2002). Low concentration of lorsban in water result in far reaching behavioral and histological effect in early stage in guppy. Ecotoxicol. Environ. Saf. 53: 248 254.

10.Devi, Y., and Mishra, A. (2013). Histopathological alterations in gill and liver anatomy of fresh water, air breathing fish Channa punctatus after Pesticide Hilban (chlorpyrifos) treatment. Adv. Biores. 4 (2): $57-$ 62.

11.Faggio, C., Fedele, G., Arfuso, F., Panzera, M., Fazio, F. (2014a). Haematological and biochemical response of Mugil cephalus after acclimation to cap- 
tivity. Cah Biol Mar 55:31-36.

12.Faggio, C., Piccione, G., Marafioti, S., Arfuso, F., Trischitta, F., Fortino, G., Fazio, F. (2014b). Monthly variations of haematological parameters of Sparus aurata and Dicentrarchus labrax reared in Mediterranean land off-shore tanks. Cah. Biol. Mar. 55:437443.

13.Gernhofer, M., Pawet, M., Schramm, M., Muller, E. and Triebskorn, R. (2001). Ultrastructural biomarkers as tools to characterize the health status of fish in contaminated streams, J. Aquat. Ecosyst. Stress Recovery, 8: 241-260.

14. Ghanbahadur, A. and Ghanbahadur, G. (2012). Histopathological effect of organochloride endosulphan. International Journal of Science.1 (2):126-127.

15.Ghasemzadeh, J., Sinaei, M., Bolouki, M. (2015). Biochemical and histological changes in fish, spotted scat (Scatophagus argus) exposed to diazinon. Bull Environ Contam. Toxicol. 94 (2):164-170.

16.Gobi, N., Vaseeharan, B., Rekha, R., Vijayakumar, S., Faggio, C. (2018). Bioaccumulation, cytotoxicity and oxidative stress of the acute exposure selenium in Oreochromis mossambicus. Ecotoxicol Environ Saf 162:147-151.

17.Hazarika, A., Sarkar, S. N., Hajare, S., Kataria, M. and Malik, J. K. (2003). Influence of malathionpretreatment on the toxicity of anilofos in male rats: A biochemical interaction study. Toxicology, 185: 1-8.

18. Jenkins, F. S., Rajanna, B. J., Shameem, U. and Mahadevi, R. (2003). Effects of sublethal concentration of endosulfan on hematological and serum biochemical parameters in the carp, Cyprinus carpio. Bull. Environ. Contam. Toxicol. 70, 993-997.

19.Jha, B. S. and Verma, B. P. (2002). Effect of pesticidal mixture on protein content in the freshwater fish Clarias batrachus , J. Ecotoxicol. Environ. Monit., 12 (3): 177-180.

20.Joseph, B. and Raj, S. J. (2011). Impact of Pesticide Toxicity on selected Biomarkers in fishes. Int. J. Zool. Res., 7(2): 212-222.

21.Jyothirmayee, S., Janetheophillus, Padma, B. T., Narender, R. and Reddy, P. U. M. (2006). Endosulfan induced changes in esterases of Anabas testudineus and Clarias batrachus. Ind. J. Comp. Anim. Physiol. 24: 95 - 99.

22.Kalender, S., Ogutcu, A., Uzunhisarciki, M., Acikgoz, F., Durak, D., Ulusoy, Y. and Kalender, Y. (2005). Diazinon induced hepatotoxicity and protective effect of vitamin $\mathrm{E}$ on some biochemical indices and ultrastructural changes. Toxicology, 211: 197-206.

23.Karamati, V., amili, S. and Ramin, M. (2010). Effect of diazinon on catalase antioxidant enzyme activity in liver tissue of Rutilus rutilus. J. Fisheries and Aqu. Sci. 5 (5): $368-376$.

24.Karmakar, S., Patra, K., Jana, S., Mandal, D. P., and Bhattacharjee, S. (2015). Exposure to environmentally relevant concentrations of malathion induces significant cellular, biochemical and histological alterations in Labeo rohita. YPEST. https:// doi.org/10.1016/j.pestbp. 2015.07.006.

25.Katuli, K. K., Amiri, B. M., Massarsky, A., Yelghi, S. (2014). Impact of a shortterm diazinon exposure on the osmoregulation potentiality of Caspian roach (Rutilus rutilus) fingerlings. Chemosphere. 108: 396404.

26.Maharajan, A. and Parurukmani, P. S. (2012). Effect of Aluminium chloride toxicity against histopathology of gill and liver tissue of Indian major carp, Catla catla (Ham.), Intl. J. Pharm. Bio. Sci., 3(3): 523-530.

27.Marigoudar, S. R, Nagarjuna, A., Karthikeyan, P., Mohan, D., and Sharma, K. V. (2018). AC SC. ECSN. https://doi.org/10.1016/j. chemosphere. 07.137.

28.Mishra, D. K., Bohidar, K. and Pandey, A. K. (2006). Histopathological changes in the liver of freshwater teleost, Channa punctatus (Bloch) exposed to sublethal concentrations of carbyl and cartap. Aquaculture., 7(1): 81-86.

29.Mishra, A. K., Mohanty, B. (2008). Acute toxicity impacts of hexavalent chromium on behavior and histopathology of gill, kidney and liver of the freshwater fish, Channa punctatus (Bloch). Environ. Toxicol. Pharmcol. 26:136-141.

30.Moraes, B. S., Loro, V. I., Ghusczak, L., Pretto, A., Menezes, C., Marchezan, E. and Machado, S. O. (2007). Effects of four rice herbicides on some metabolic and toxicology parameters of teleost fish, Leporinus otusidens. Chemosphere, 68: 1597 - 1601.

31.Muley, D. V., Karanjkar, D. M. and Maske, S. V. (2007). Impact of industrial effluents on the biochemical composition of freshwater fish, Labeo rohita. J. Environ. Biol. 28, 245-249.

32. Muthukumaravel, K., sukumaran, M. and Sathick, O. (2013). Studies on the acute toxicity of pesticides on the fresh water fish Labeo rohita. J. Pure Appl. Zool. 1 (2): 185 - 192.

33.Nagaraju, B. and Rathnamma, V. V. (2013). Effect of profenofos an organophosphate on protein levels in some tissues of freshwater fish Labeo rohita (Ham.). International Journal of Pharmacy and Pharmaceutical Sciences, 5(1): 276-279.

34.Ogueji, E. O., Usman, I. B., Auta, J. (2013). Histopathology of liver and gill of Clarias gariepinus (Burchell 1822) with swollen abdomen following exposure to acute and sub-lethal concentrations of chlorpyrifos-ethyl. Int. J. Basic Appl. Sci. 2: 223.

35.Oruç, E. (2012). Oxidative stress responses and recovery patterns in the liver of Oreochromis niloticus exposed to chlorpyrifos-ethyl. Bull Environ Contam Toxicol 88:678-684.

36.Pandey, A. K., Mishra, D. K. and Bohidar, K. (2014). Histopathological changes in gonadotrophs of Channa punctatus (Bloch) exposed to sublethal concentration of carbaryl and cartap. J. Exp. Zool. India 17, 451 -455 .

37.Prashanth, M. S. and Neelagund, S. E. (2008). Impact of cypermethrin on enzyme activities in the freshwater fish Cirrhinus mrigala (Ham.)., J. Caspian. J. Env. Sci., 6(2): 91-95.

38.Rao, A. S. and Pillala, R. R. (2001). The concentration of pesticides in sediments from Kolleru Lake in India. Pest Manag. Sci. 57, 620-624.

39. Ravanaiah, G. and Narasimha Murthy, C. V. (2010). Impact of aquaculture and industrial pollutants of Nellore district on histopathological changes in the liver and intestine tissue of fish, Tilapia mossambica. National J. Life Sciences, 7 (2): 110 - 115.

40.Rawat, D. K., Bais, V. S. and Agrawal, N. C. (2002). A correlative study on liver glycogen and endosulfan toxicity in Heteropneustes fossilis (Bloch). J. Environ. Biol. 23, 205-207.

41.Remia, K. M., Logaswamy, S., Logankumar, K. and Rajmohan, D. (2008). Effect of an insecticide (Monocrotophos) on some biochemical constituents of the fish Tilapia mossambica. Poll. Res., 27 (3): 523 - 526. 
42.Rohanker, P., Zane, V., Dabhadkar, D. and Labhsetuwar, N. (2012). Evaluation of impact of phosphomedon on protein status of fresh water fish Channa punctatus., Indian Sci. Res., 3: 123-126.

43.Rosety-Rodrı́́ uez, M., Ordoñez, F. J., Rosety, M., Rosety, J. M., Rosety, I., Ribelles, A. and Carrasco, C. (2002). Morpho-histochemical changes in the gills of turbot, Scophthalmus maximus L., induced by sodium dodecyl sulfate. Ecotoxicol Environ Saf 51 (3):223-228.

44. Sayeed, I., Parvez, S., Pandey, S., Bin-Hafeez, B. Haque, R. And Raisudin, S. (2003). Oxidative stress biomarkers of exposure to deltamethrin in fresh water fish, Channa punctatus. Bloch. Ecotoxicol. Environ. Saf. 56: $295-301$.

45.Schwaiger, J., Wanke, R., Adam, S., Pawert, M., Honnen, W. and Triebskorn, R. (1997). The use of histopathological indicators to evaluate contaminant related stress in fish. J. Aquat. Ecosyst. Stress Recovery, 6: 75-86.

46.Senapati, T., Samanta, P., Mandal, S. and Ghosh, A. R. (2013). Study on histopathological, histochemical and enzymological alterations in stomach and intestine of Anabas testudineus (cuvier) exposed to Almix 20WP herbicide. International Journal of Food, Agriculture and Veterinary Sciences. 3 (2):100-111.

47. Sharma, R. R., Pandey, A. K. and Shukla, G. R. (2001). Histopathological alterations in fish tissues induced by toxicity. Aquaculture. 2 (1):31-43.

48.Sulfath, P. P., Hari Sanker, H. S. and Bijoy Nandan, S. (2013). Effect of organochlorine pesticide, lindane on the antioxidant activity of Oreochromis mossambicus. J. Appl. Biol Fish. 1 (1\&2): $97-105$.

49.Susan, A. T., Veeraiah, K. and Tilak, K. S. (1999). Biochemical and enzymatic changes in tissues of Catla catla exposed to the pyrithroid fenvalerate, J. Ecobiol., 11(2):109-116.

50.Teh, S. J., Adams, S. M. and Hinton, D. E. (1997). Histopathological biomarkers in feral freshwater fish populations exposed to different types of contaminant stress. Aquat. Toxicol., 37: 51-70.

51.Tilak, K. S. and Yacob, K. (2002). Toxicity and effect of fenvalerate on fish Ctenopharyngo donidellus, $\mathrm{J}$. Ecotoxicol. Environ. Monit., 12: 9-15.

52.Tilak, K. S., Veeraiah, K. and Vardhan, K. S. (2003). Toxicity and residue studies of Fenvalerate to the freshwater fish Channa punctatus., Bull. Environ.
Contam. Toxicol., 71: 1207-1212.

53.Tilak, K., Rao, K. and Veeraiah, K. (2005). Effects of chlorpyrifos on histopathology of the fish Catla catla., J. Ecotoxicol. Environ. Monit., 15(2): 127-140.

54.Tiwari, S. and Singh, A. (2009). Changes in some biochemical parameters in the liver and muscle of Colisa fasciatus due to toxicity of ethanolic extract of Narium indicum (Lal Kaner) latex. Nat. Prod. Radi. 8 48-54.

55.Tripathi, G. and Singh, H. (2013). Impact of Alphamethrin on biochemical parameters of Channa punctatus. Journal of Environmental Biology, 34: 227-230.

56. Tripathi, V. K. and Yadav, R. K. (2015). Effect of pesticide (Organophosphorous) on aquatic fish Labeo rohita. Int. J. Chem. Sci. 13 (2): 625 - 640.

57.Ullah, S. and Zorriehzahra, M. J. (2015). Ecotoxicology: a review of pesticides induced toxicity in fish. Adv. Anim. Vet. Sci. 3, 40-57.

58.Ullah, R., Zuberi, A., Ullah, S., Ullah, I. and Dawar, F. U. (2014). Cypermethrin induced behavioural and biochemical changes in mahseer, Tor putitora. $J$. Toxicol. Sci. 39, 829-836.

59.Van der Oost, R., Beyer, J. and Vermeulen, N. P.E. (2003). Fish bioaccumulation and biomarkers in environmental risk assessment: a review. Environ. Toxicol. Pharmacol. 13: 57 - 149.

60.Velmurugan, B., Selvanayagam, M., Cengiz, E. I. And Unlu, E. (2007). The effects of monocrotophos to different tissues of freshwater fish Cirrhinus mrigala. Bulletin envi. Conta. Toxicol. 78 (6): $450-454$.

61.Venkataramana, G. V., Sandhya Rani, P. N. and Murthy, P. . (2006). Impact of malathion on the biochemical parameters of gobild fish Glossogobius giuris (Ham.), J. Environ. Bio., 27(1): 119-122.

62.Vishal, T. (2004). Hepatotoxicity of organophosphorus compound malathion on the protein metabolism in Cirrhinus mrigala (Ham.), J. Curr. Sci., 5(2): 661-664.

63.Yeragi, S. G., Rana, A. M. And Koli, V. A. (2003). Effect of pesticide on protein metabolism of Mudskipper, Boleophthalmus dussumieri. J. Ecotoxicol. Environ. Monit. 13 (3): $211-214$.

64.Zahran E, Risha E, Awadin W (2018) Acute exposure to chlorpyrifos induces reversible changes in health parameters of Nile tilapia (Oreochromis niloticus). 197 (November 2017): 47-59. https://doi. org/10.1016/ j.aquatox.2018.02.001. 